\title{
PENGUKURAN KEPUASAN PELAYANAN MENGGUNAKAN METODE SERVQUAL
}

\author{
Yayang Eluis Bali Mawartika \\ Program Studi Sistem Informasi STMIK Bina Nusantara Jaya \\ Jl. Yos Sudarso No. 97 A Jawa Kanan, Lubuklinggau Timur II, Kota Lubuklinggau, 31621 \\ E-mail : yayangeluisbm@gmail.com
}

\begin{abstract}
A large agency that provides services must continue to improve the quality of its services. However, customer satisfaction with services is difficult to measure, so that leaders experience obstacles to making decisions in improving service, therefore we need a system that can measure the level of service quality so that it becomes a tool in making the decision making process to improve service quality. To develop this system using the Servqual method. This method confirms that if the performance on an attribute (attribute performance) increases greater than the expectation of the attribute concerned, then the perception of service quality will be positive, and vice versa. This system serves to assist decision makers in determining strategies to improve the quality of appropriate services.
\end{abstract}

Keywords: service quality, service satisfaction, servqual

\begin{abstract}
Abstrak
Sebuah instansi besar yang memberikan pelayanan jasa harus terus meningkatkan kualitas pelayanannya. Namun, kepuasan pelanggan terhadap pelayanan sulit untuk diukur, sehingga para pimpinan mengalami kendala untuk mengambil keputusan dalam meningkatkan pelayanan, oleh karena itu diperlukan suatu sistem yang dapat mengukur tingkat kualitas pelayanan sehingga menjadi alat bantu dalam melakukan proses pengambilan keputusan untuk meningkatkan kualitas pelayanan. Untuk mengembangkan sistem ini menggunakan metode Servqual. Metode ini menegaskan bahwa bila kinerja pada suatu atribut (attribute performance) meningkat lebih besar daripada harapan (expectation) atas atribut yang bersangkutan, maka persepsi terhadap kualitas jasa akan positif, demikian pula sebaliknya. Sistem ini berfungsi untuk membantu pihak pengambil keputusan dalam menentukan strategi meningkatkan kualitas pelayanan yang tepat.
\end{abstract}

Kata kunci: kualitas pelayanan, kepuasan pelayanan, servqual

\section{Pendahuluan}

Pelayanan adalah kegiatan yang dilakukan oleh seseorang atau sekelompok orang dengan landasan faktor materi melalui sistem, prosedur dan metode tertentu dalam rangka memenuhi kepentingan orang lain sesuai dengan haknya [1]. Pelayanan adalah suatu aktivitas atau serangkaian aktivitas yang bersifat tidak kasat mata (tidak dapat diraba) yang terjadi sebagai akibat adanya interaksi antara konsumen dengan karyawan atau hal-hal lain yang di sediakan oleh perusahaan pemberi pelayanan yang dimaksudkan untuk memecahkan permasalahan konsumen atau pelanggan [2]. Pelayanan dapat diartikan sebagai proses pemenuhan kebutuhan melalui aktivitas secara langsung yang diberikan oleh suatu instansi kepada masyarakat dengan tujuan untuk dapat memberikan kepuasan kepada masyarakat. Kualitas suatu instansi juga sering dilihat dari kualitas pelayanan yang diberikan oleh instansi tersebut. Untuk itu sudah sewajarnya jika suatu instansi sangat mengutamakan kualitas pelayanan yang berperan penting dalam kegiatan instansi. Tentu saja hal yang paling mendasar adalah ukuran tingkat kualitas pelayanan yang dimiliki instansi harus dapat ditingkatkan dengan maksimal. Dengan kata lain, kualitas pelayanan dalam suatu instansi harus terus ditingkatkan.

Badan Pelayanan Perizinan Terpadu dan Penanaman Modal (BPPT-PM) Kota Lubuklinggau merupakan sebuah instansi pemerintah yang bergerak dibidang pelayanan perizinan yang menangani berbagai macam masalah perizinan dan sebagai penyedia layanan pengelolaan penanaman modal bagi para investor. Sebagai instansi pemerintah yang bergerak dibidang pelayanan, kualitas pelayanan kepada masyarakat perlu terus ditingkatkan, sehingga mencapai kualitas yang diharapkan. Akan tetapi BPPT-PM Kota Lubuklinggau mengalami kesulitan dalam mengukur kualitas pelayanannya, karena belum memiliki suatu sistem yang mempermudah perhitungan tingkat kualitas pelayanan dan tidak ada sistem yang mendukung keputusan untuk meningkatkan kualitas pelayanan tersebut. Akibatnya pengambil keputusan dalam hal ini pimpinan BPPT-PM Kota Lubuklinggau mengalami kesulitan dalam menentukan strategi yang berhubungan dengan peningkatan kualitas pelayanan, karena pengambil keputusan hanya menggunakan intuisi setiap kali membuat keputusan strategis yang berhubungan dengan kualitas pelayanan. Tentu saja ketergantungan terhadap intuisi tersebut tidak selalu menghasilkan keputusan 
yang benar. Jika dibiarkan terus menerus, hal ini akan diterima (perceived service) sesuai dengan yang berdampak negatif dan menghambat kemajuan BPPT- diharapkan, maka kualitas jasa dipersepsikan baik dan PM Kota Lubuklinggau dalam hal peningkatan kualitas memuaskan. Jika jasa yang diterima melampaui harapan pelayanan kepada masyarakat. pelanggan, maka kualitas jasa dipersepsikan sebagai kualitas yang ideal. Sebaliknya, jika jasa yang diterima

Salah satu solusi yang dapat digunakan untuk lebih rendah dari yang diharapkan, maka kualitas jasa menyelesaikan masalah tersebut adalah dengan dipersepsikan buruk. [7] menerapkan sistem yang dapat mengukur tingkat kualitas pelayanan menggunakan metode Servqual Ilustrasi model Servqual secara konseptual dapat dilihat dikarenakan metode ini merupakan metode yang paling pada Gambar 1 gambar tersebut merupakan efektif untuk mengetahui ukuran kualitas pelayanan penyederhanaan dari model yang dibuat oleh dengan cara membandingkan dua faktor utama, yaitu Zeithaml.[8] Dalamilustrasi tersebut, kualitas pelayanan persepsi masyarakat atas layanan nyata yang mereka diukur melalui pengukuran 5 gap (kesenjangan atau terima dengan layanan yang sesungguhnya yang perbedaan penilaian). Kelima gap tersebut diukur diharapkan atau diinginkan. Jika kenyataan kurang dari dengan meninjau pendapat pelanggan dan pihak yang diharapkan, maka layanan dikatakan tidak bermutu manajemen terhadap kualitas pelayanan. dan apabila kenyataan sama dengan harapan maka layanan tersebut dikatakan bermutu.

\section{Tinjauan Pustaka}

\subsection{Kualitas Jasa}

Kualitas jasa sebagai ukuran seberapa bagus tingkat pelayanan yang diberikan mampu sesuai dengan ekspetasi pelanggan. Berdasarkan definisi ini, kualitas jasa dapat diwujudkan melalui pemenuhan kebutuhan dan keinginan pelanggan serta ketetapan penyampaiannya mengimbangi harapan pelanggan. [3] Kualitas jasa atau layanan mencakup empat hal yaitu atribut layanan pelanggan, pendekatan untuk penyempurnaan kualitas jasa, sistem umpan balik untuk kualitas layanan pelanggan, dan implementasi [4].

\subsection{Servqual}

Model pengukuran kualitas jasa yang paling popular adalah model Servqual (Service Quality) yang dikembangkan oleh Parasuraman, Zethaml, dan Berry [5]. Model yang dikenal dengan istilah Gap Analysis Model ini berkaitan erat dengan model kepuasan pelanggan yang didasarkan pada pedoman diskonfirmasi. Pedoman ini menegaskan bahwa bila kinerja pada suatu atribut (attribute performance) meningkat lebih besar daripada harapan (expectation) atas atribut yang bersangkutan, maka persepsi terhadap kualitas jasa akan positif, demikian pula sebaliknya.

Untuk mengukur kepuasan pelanggan digunakan metode Servqual (Sevice Quality). Kelebihan dari penggunaan metode ini terletak pada kemampuannya untuk menangkap subjektifitas yang terjadi pada pengumpulan data yang diambil melalui kuesioner, dan kemampuannya untuk dapat mengetahui variabelvariabel yang harus diperhatikan untuk selalu ditingkatkan berdasarkan nilai potensial kepuasan pelanggan, sehingga perusahaan dapat mengetahui fasilitas- fasilitas apa saja yang dianggap penting dan berpengaruh terhadap kepuasan pelanggan terhadap pelayanan bengkel tersebut. [6] Apabila jasa yang 


\subsection{Pengukuran Servqual}

Pengukuran kualitas jasa dalam model Servqual ini didasarkan pada skala multi item yang dirancang untuk mengukur harapan dan persepsi pelanggan. Serta Gap diantara keduanya pada lima dimensi kualitas jasa yaitu (Reliability, Assurance, Tangibles, Emphaty, Responsiveness), kelima dimensi kualitas tersebut dijabarkan dalam beberapa butir pertanyaan untuk atribut harapan dan variable persepsi berdasarkan skala likert. Skor Servqual untuk tiap pasang pertanyaan bagi masing-masing pelanggan dapat dihitung berdasarkan rumus berikut [8] :

SKOR SERVQUAL $=$ SKOR PERSEPSI - SKOR HARAPAN

Skor Gap kualitas jasa pada berbagai level secara rinci dapat dihitung berdasarkan [8]:
Untuk rata-rata jawaban responden pada pernyataan harapan dapat dihitung dengan persamaan [8] :

$$
\square\left[=\frac{\Sigma \square \square}{\square}\right.
$$

\section{Keterangan :}

$Y i=$ rata-rata jawaban responden untuk pernyataan harapan atribut ke-i

$\frac{\sum \square \square}{\square} \quad=$ jumlah bobot jawaban pernyataan harapan atribut ke-i

n $\quad=$ jumlah responden

Perhitungan kenyataan atau persepsi pelayana yang dirasakan oleh pelanggan [8] :

$\sum x i=\left(\sum S T T \times 1\right)+\left(\sum T T \times 2\right)+\left(\sum C T\right.$

$\times 3)+\left(\sum T \times 4\right)+\left(\sum S T \times 5\right)$

a. Item-by-item analysis, missal $\mathrm{P} 1-\mathrm{H} 1, \mathrm{P} 2-\mathrm{H} 2$, dst.

Untuk rata-rata jawaban responden pada pernyataan

b. Dimensi-by-dimensi analysis, contoh: $(\mathrm{P} 1+\mathrm{P} 2$ kenyataan dapat dihitung dengan persamaan [8]: $+\mathrm{P} 3+\mathrm{P} 4 / 4)-(\mathrm{H} 1+\mathrm{H} 2+\mathrm{H} 3+\mathrm{H} 4 / 4)$ dimana P1 sampai P4 dan H1 sampai $\mathrm{H} 4$ mencerminkan 4 pertanyaan persepsi dan harapan berkaitan dengan dimensi tertentu.

c. Perhitungan ukuran tunggal kualitas jasa atau gap Servqual yaitu (P1 + P2 + P3 ... + P22 / Keterangan : 22) $-(\mathrm{H} 1+\mathrm{H} 2+\mathrm{H} 3 \ldots+\mathrm{H} 22 / 22)$.

\subsection{Perhitungan kualitas jasa berdasarkan atribut atau pertanyaan Servqual gap 5}

Perhitungan harapan atau ekspetasi pelanggan mengenai pelayanan jasa [8]:

$\sum y i=\left(\sum S T T \times 1\right)+\left(\sum T T \times 2\right)+\left(\sum C T\right.$

$\times 3)+\left(\sum T \times 4\right)+\left(\sum S T \times 5\right)$

Keterangan :

$\sum y i \quad=$ jumlah bobot jawaban pertanyaan harapan ke-i

$\sum S T T=$ jumlah orang yang memilih jawaban sangat tidak terpenuhi

$\sum T T=$ jumlah orang yang memilih jawaban tidak terpenuhi

$\sum C T=$ jumlah orang yang memilih jawaban cukup terpenuhi

$\sum T \quad=$ jumlah orang yang memilih jawaban terpenuhi

$\sum S T \quad=$ jumlah orang yang memilih jawaban sangat terpenuhi

1,2,3,4,5 = skor untuk skala Likert

$$
\square=\frac{\Sigma \square \square}{\square}
$$

$X i=$ rata-rata jawaban responden untuk

$\frac{\sum \square}{\square} \quad=$ jumlah bobot jawaban pernyataan kenyataan atribut ke-i

$\mathrm{n} \quad=$ jumlah responden

Nilai Gap 5 adalah nilai kesenjangan yang terjadi antara harapan dan kenyataan pengguna jasa yang diperoleh dari pernyataan kualitas pelayanan jasa tentang harapan konsumen terhadap pelayanan yang ingin dirasakan dan nilai rata-rata kenyataan pelayanan yang dirasakan konsumen pada kondisi sebenarnya. Untuk mengetahui nilai gap tersebut digunakan persamaan berikut :

$$
S Q_{i=X i}-Y i
$$

Keterangan :

$S Q_{i} \quad=$ nilai gap atribut ke- $\mathrm{i}$

$X i \quad=$ nilai rata-rata kenyataan atribut ke- $\mathrm{i}$

$Y i \quad=$ nilai rata-rata harapan atribut ke- $\mathrm{i}$

\subsection{Perhitungan Kualitas Jasa Berdasarkan Dimensi Servqual Gap 5}

Perhitungan rata-rata jawaban antara harapan pelanggan mengenai pelayanan jasa terhadap kenyataan pelayanan yang dirasakan oleh pelanggan berdasarkan pernyataan kenyataan atribut ke i 
lima dimensi Parasuraman Servqual Model yang terdiri Keterangan :

atas reliability (keandalan), responsiveness (daya $S Q D_{i} \quad=$ nilai gap untuk dimensi ke-i

tanggap), assurance (jaminan), emphaty (empati), $X D_{i} \quad=$ nilai rata-rata kenyataan untuk dimensi ke-i

tangibles (bukti fisik).

$Y D_{i} \quad=$ nilai rata-rata harapan untuk dimensi ke-i

Perhitungan bobot rata-rata atribut pernyataan per dimensi untuk harapan :

$$
\sum Y P_{i=} Y_{1}+Y_{2}+\ldots+Y_{n}
$$

\section{Keterangan :}

$\sum Y P_{i} \quad=$ jumlah nilai rata-rata atribut pernyataan per dimensi ke-i harapan

Perhitungan rata-rata jawaban per dimensi nilai gap 5 untuk harapan :

$$
Y D_{i}=\frac{\Sigma \square \square \square}{\square}
$$

Keterangan :

$Y D_{i} \quad=$ rata-rata dimensi atribut ke-i untuk harapan

$\sum Y P i=$ jumlah nilai rata-rata atribut pernyataan per dimensi ke-i harapan

$n \quad=$ jumlah pernyataan per dimensi

Perhitungan bobot rata-rata atribut pernyataan per dimensi untuk kenyataan :

$$
\sum X P_{i=} X_{1}+X_{2}+\ldots+X_{n}
$$

Keterangan :

$\sum X P_{i}=$ jumlah nilai rata-rata atribut pernyataan per dimensi ke-i kenyataan.

Perhitungan rata-rata jawaban per dimensi nilai gap 5 untuk kenyataan :

$$
X D_{i}=\frac{\sum \square \square \square}{\square}
$$

Keterangan :

$X D_{i} \quad=$ rata-rata dimensi atribut ke-i untuk kenyataan

$\sum X P_{i} \quad=$ jumlah nilai rata-rata atribut pernyataan per dimensi ke-i kenyataan

$\mathrm{n} \quad=$ jumlah pernyataan per dimensi

Untuk mengetahui nilai kesenjangan (gap 5) digunakan persamaan sebagai berikut :

$$
S Q D_{i=} X D_{i}-Y D_{i}
$$

Semakin besar gap atau kesenjangan (gap tersebut menjauhi nol atau negatif) yang dihasilkan dari sebuah perhitungan Servqual Gap 5 ini, semakin kurang baiknya kualitas pelayanan jasa tersebut. Oleh karena itu, prioritas perbaikan kualitas pelayanan jasa dilakukan dari gap terbesar. Sebaliknya semakin kecilnya nilai gap (gap tersebut mendekati nol atau positif) semakin baik kualitas pelayanan jasa tersebut.

\section{Metodologi Penelitian}

\subsection{Analisis Masalah}

Berdasarkan hasil penelitian yang dilakukan, didapatkan bahwa kualitas pelayanan diukur berdasarkan unsurunsur pengukuran kualitas pelayanan yang dimiliki oleh Badan Pelayanan Perizinan Terpadu dan Penanaman Modal Kota Lubuklinggau, pengukuran kualitas pelayanan didapatkan dari hasil penilaian masyarakat selaku responden mengenai pelayanan yang mereka terima, namun proses pengukuran kualitas pelayanan tersebut dilakukan secara keseluruhan tidak diukur perunsur kualitas pelayanan, sehingga tidak diketahui unsur pelayanan mana yang mengalami kelemahan dan perlu ditingkatkan serta unsur pelayanan mana yang harus dipertahankan. Hal ini menyebabkan pihak pengambil keputusan sulit untuk menentukan strategi meningkatan kualitas pelayanan yang sesuai dengan unsur pelayanan yang mengalami kelemahan dan perlu ditingkatkan.

\subsection{Analisis Pemecahan Masalah}

Unsur-unsur pengukuran kualitas pelayanan yang ada di BPPT-PM Kota Lubuklinggau dinilai oleh masyarakat selaku responden. Namun, proses pengukuran kualitas pelayanan tersebut dilakukan secara keseluruhan, tidak diukur per-unsur pelayanannya. Hal ini menyebabkan pengambil keputusan mengalami kesulitan untuk menentukan strategi peningkatan kualitas pelayanan yang tepat dan sesuai dengan unsur pelayanan yang harus ditingkatkan, karena hasil dari proses pengukuran kualitas pelayanan yang dilakukan secara keseluruhan tidak diketahui unsur pelayanan mana yang mengalami kelemahan sehingga perlu ditingkatkan dan unsur pelayanan mana yang harus dipertahankan.

Untuk membantu menyelesaikan masalah tersebut diperlukan suatu sistem yang dapat mengukur kualitas pelayanan per-unsur pelayanannya dan bisa digunakan sebagai alat bantu dalam pengambilan keputusan untuk menentukan strategi yang tepat dan sesuai untuk meningkatkan kualitas pelayanan.

Dengan mempertimbangkan hal tersebut maka diperlukan dilakukan pengukuran tingkat kualitas pelayanan. Hasil pengukuran tersebut dimaksudkan sebagai alat bantu bagi para pengambil keputusan dalam menentukan strategi meningkatkan kualitas pelayanan, namun tidak untuk menggantikan keputusan. 
Kualitas pelayanan terdiri dari 5 (lima) dimensi utama dengan lima dimensi servqual. Kemudian survey berupa yaitu bukti fisik (tangibles), keandalan (reliability), daya kuesioner disebarkan kepada repsonden atau masyarakat tanggap (responsiveness), jaminan (assurance), dan yang datang ke BPPT-PM untuk melaksanakan empati (empathy).

a. Bukti Fisik meliputi fasilitas fisik, tersebut didapatkan data berupa data hasil survey yang perlengkapan, pegawai, dan sarana komunikasi. kemudian diinputkan ke sistem. Sistem ini

b. Keandalan merupakan kemampuan menghasilkan laporan berupa hasil pengukuran kualitas memberikan layanan yang dijanjikan dengan layanan yaitu laporan hasil hitung servqual per atribut segera, akurat dan memuaskan.

dan hasil hitung servqual per dimensi yang nantinya

c. Daya Tanggap merupakan keinginan para staf digunakan sebagai acuan oleh pimpinan instansi untuk untuk membantu para pelanggan dan mengambil keputusan dalam menentukan strategi memberikan layanan dengan tanggap. perbaikan layanan guna meningkatkan kualitas

d. Jaminan mencakup pengetahuan, kompetensi, pelayanan.

kesopanan, dan sifat dapat dipercaya yang dimiliki para staf; bebas dari bahaya, resiko atau keragu-raguan.

e. Empati meliputi kemudahan dalam menjalin relasi, komunikasi yang baik, perhatian pribadi dan pemahaman atas kebutuhan individual para pelanggan.

\section{Hasil dan Pembahasan}

Kriteria yang terdapat dalam sistem mengukur tingkat kualitas pelayanan yang dibangun oleh penulis berasal dari unsur-unsur pengukuran kualitas pelayanan yang dimiliki Badan Pelayanan Perizinan Terpadu dan Penanaman Modal Kota Lubuklinggau yang diklasifikasikan kedalam 5 dimensi metode Servqual. Proses pengukuran kualitas pelayanan dengan menggunakan sistem ini dilakukan berdasarkan dimensi dan berdasarkan pertanyaan, sehingga mempermudah pengambil keputusan untuk menentukan strategi meningkatkan kualitas pelayanan yang tepat dan sesuai, karena sistem ini menghasilkan ukuran kualitas pelayanan per-dimensi dan per-pertanyaan, sehingga bisa diketahui unsur pelayanan mana yang mengalami kelemahan dan perlu ditingkatkan serta unsur pelayanan mana yang harus dipertahankan.

\subsection{Diagram Konteks}

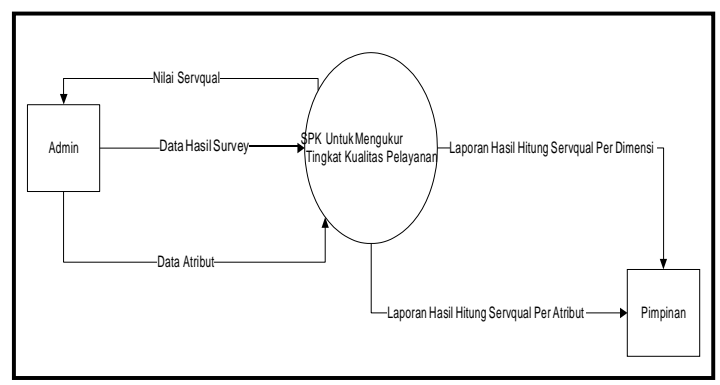

Gambar 2 Diagram Konteks

\subsection{Data Flow Diagram (DFD) Level 1}

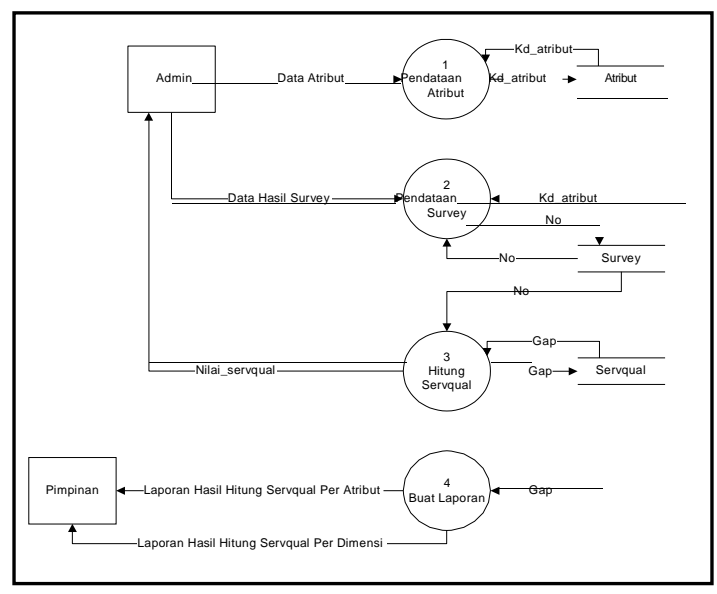

Gambar 3 DFD Level 1

Pada gambar 3 digambarkan bahwa sistem memiliki 4 proses yaitu proses pendataan atribut, proses pendataan hasil survey, proses hitung servqual dan proses pembuatan laporan. Pada level 1 ini, admin memberikan inputan berupa data atribut dan data hasil survey yang kemudian data-data tersebut disimpan kedalam database yang sesuai dengan file-file tersebut. Proses hitung servqual digunakan untuk mengetahui besarnya kesenjangan antara tingkat harapan dari pelayanan yang diinginkan masyarakat dengan kenyataan pelayanan yang dirasakan masyarakat. Proses hitung servqual ini diambil dari hasil survey dari para responden. Setelah proses hitung servqual selesai, maka pimpinan akan menerima laporan berupa laporan hasil hitung servqual berdasarkan atribut dan laporan hasil hitung servqual berdasarkan dimensi. Kedua laporan ini nantinya dapat digunakan sebagai acuan oleh pimpinan instansi untuk mengambil keputusan dalam menentukan strategi perbaikan layanan guna meningkatkan kualitas

Gambar 2 menjelaskan tentang alur data pada sebuah pelayanan.

proses sistem [9]. Pada proses pengukuran kualitas pelayanan di BPPT-PM Kota Lubuklinggau. Admin memberikan inputan berupa data atribut dan data hasil survey. Data atribut dalam hal ini adalah pertanyaanpertanyaan yang diajukan untuk responden sesuai 


\subsection{Entity Relationship Diagram (ERD)}

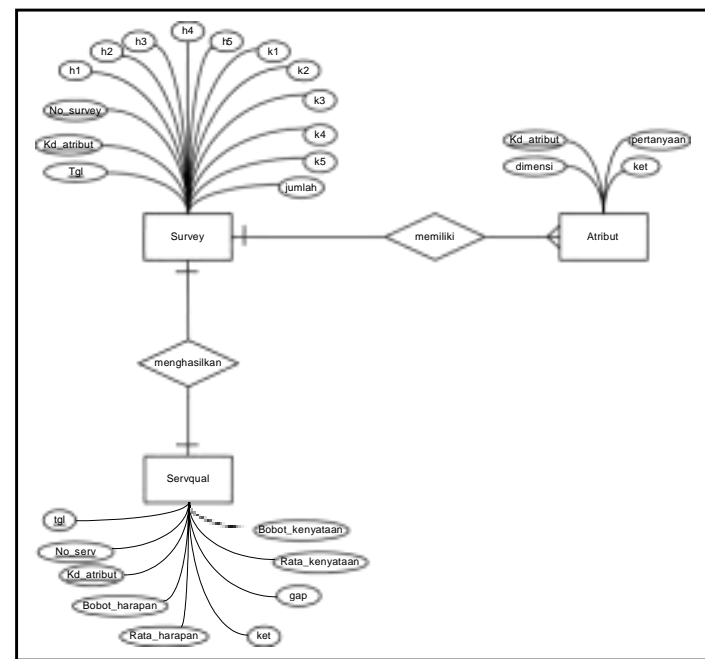

Gambar 4 Entity Relationship Diagram (ERD) [10]

\subsection{Implementasi Sistem}

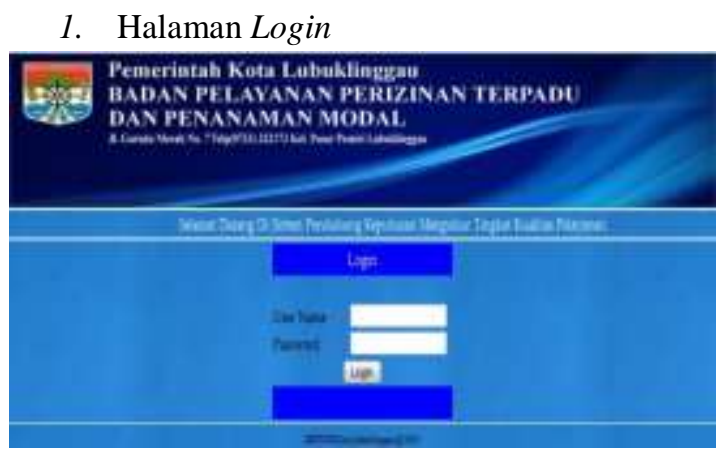

Gambar 5 Halaman Login

Pada halaman ini user dapat melakukan input data login berupa nama pengguna dan kata sandi untuk mendapatkan hak akses ke dalam SPK. Halaman login berfungsi untuk menghindari adanya pihak-pihak yang tidak berwenang untuk mendapatkan atau mengolah data yang ada di dalam sistem.

2. Halaman Menu Utama

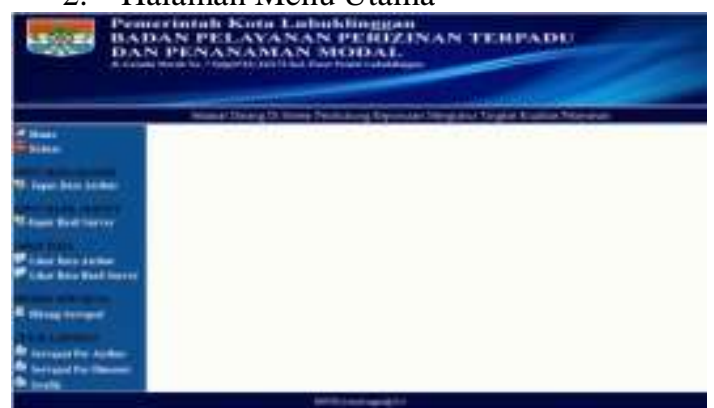

Gambar 6 Halaman Menu Utama

Halaman ini adalah halaman utama, pada halaman ini user dapat memilih salah satu menu yang ada sesuai dengan kebutuhan. Menu utama terdiri dari input, lihat data, perhitungan dan laporan.

3. Halaman Proses Hitung Servqual
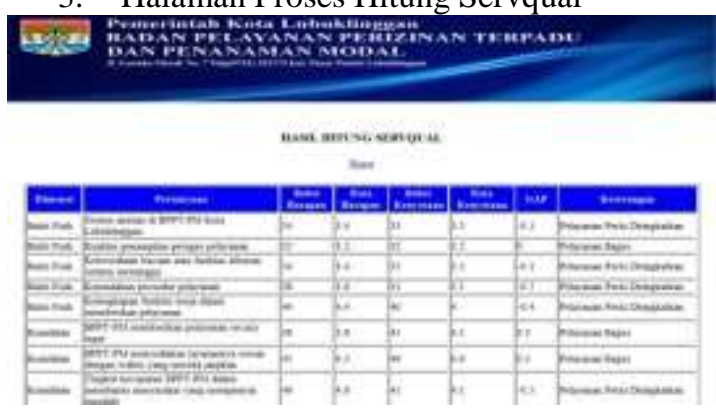

Gambar 7 Halaman Proses Hitung Servqual Per Atribut

Pada halaman perhitungan servqual user dapat melihat hasil proses perhitungan servqual berdasarkan atribut, yang prosesnya menghitung data hasil survey kemudian dilakukan penilaian kesenjangan (gap). Pada halaman hitung servqual ini, data hasil survey yang belum lengkap atau belum sampai 22 tidak dapat dilakukan proses hitung servqual, jadi yang diproses hanya data hasil survey yang sudah lengkap.

\begin{tabular}{|c|c|c|c|c|c|c|}
\hline Vinati & Bumbering & Buthene & Bawleaten & Panlegtum & GP & Elengug \\
\hline & 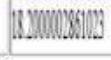 & batomb & 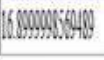 & \multicolumn{3}{|c|}{ 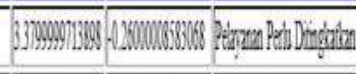 } \\
\hline & 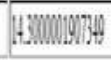 & 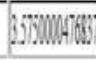 & 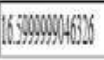 & \multicolumn{3}{|c|}{ 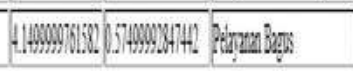 } \\
\hline 7 & 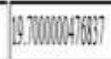 & 340000936 & $190000-3 x+1$ & \multicolumn{3}{|c|}{ 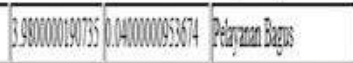 } \\
\hline$z$ & [63:00616i2] & 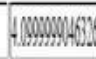 & 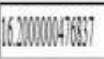 & \multicolumn{3}{|c|}{ 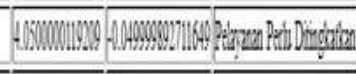 } \\
\hline & 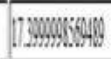 & 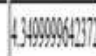 & 16090901630 & \multicolumn{3}{|c|}{ 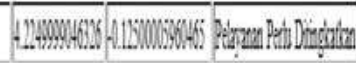 } \\
\hline
\end{tabular}

Gambar 8 Halaman Proses Hitung Servqual Per Dimensi

Pada halaman perhitungan servqual user dapat melihat hasil proses perhitungan servqual berdasarkan dimensi, yang prosesnya menghitung data hasil survey kemudian dilakukan penilaian kesenjangan (gap).

4. Laporan Servqual Per Atribut

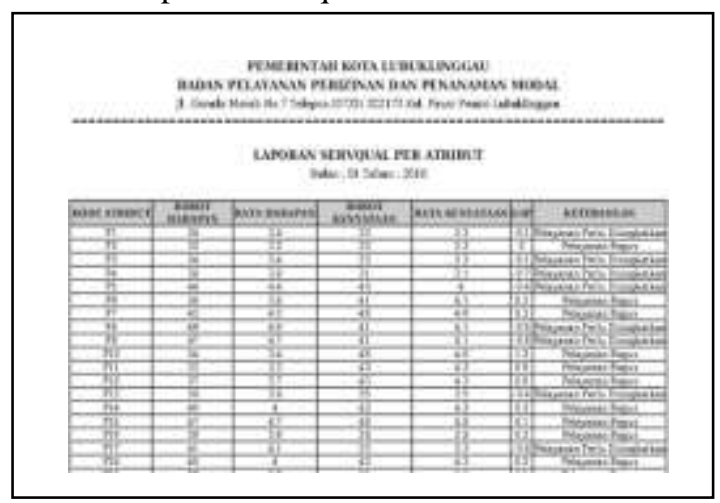

Gambar 9 Laporan Servqual Per Atribut 


\section{Laporan Servqual Per Dimensi}

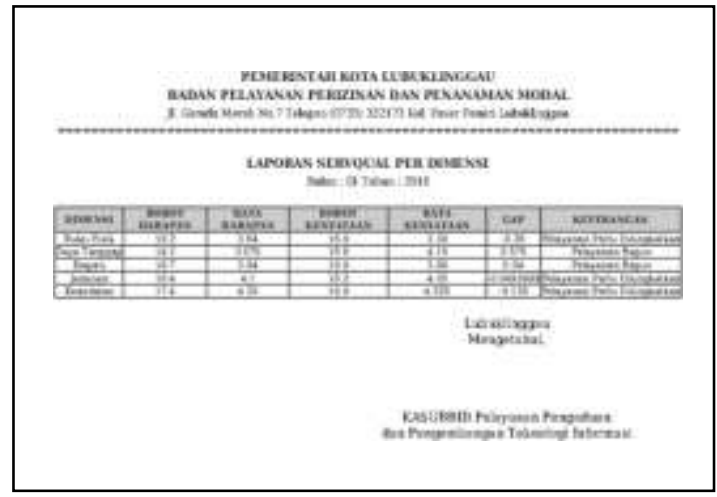

Gambar 10 Laporan Servqual Per Dimensi

6. Laporan Servqual Dalam Bentuk Grafik

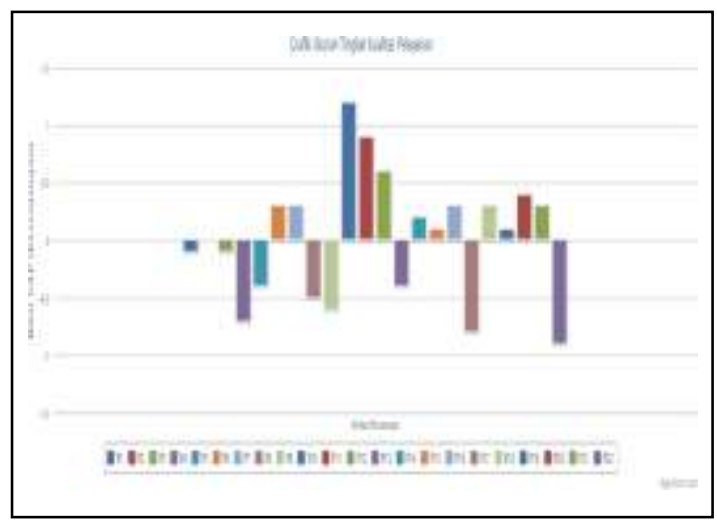

Gambar 11 Grafik Ukuran Tingkat Kualitas

\section{Kesimpulan}

\subsection{Simpulan}

Berdasarkan hasil penelitian telah dilakukan, maka didapat suatu hasil kesimpulan, yakni :

1. Untuk mengukur kualitas pelayanan perdimensi dapat menggunakan metode servqual, karena metode servqual merupakan metode yang mengukur kualitas pelayanan dengan cara membandingkan persepsi masyarakat atas layanan nyata yang mereka terima dengan layanan yang sesungguhnya mereka harapkan berdasarkan dimensi-dimensi pelayanannya.

2. Penerapan sistem untuk mengukur tingkat kualitas pelayanan menggunakan metode servqual menghasilkan ukuran kualitas pelayanan yang proses perhitungannya menggunakan perhitungan nilai kesenjangan (gap 5).

\subsection{Saran}

1. Untuk pengembangan selanjutnya, subdimensi yang digunakan di sistem pengukuran kualitas pelayanan dapat ditambah, sehingga dapat menghasilkan sistem yang dinamis.

2. Penelitian hanya menghasilkan perhitungan ukuran kualitas pelayanan, untuk kedepannya dapat dikembangkan menjadi sistem yang lebih besar lagi.

\section{Daftar Rujukan}

[1] Moenir, H.A.S., 2001, Manajemen Pelayanan Umum di Indonesia, Bumi Aksara, Jakarta.

[2] Groroos, Michael, 1990, Perceived Service Quality Model. Published Ohio University Press, California.

[3] Tjiptono F, 2014, Pemasaran Jasa, Andi Offset : Yogyakarta.

[4] Tjiptono F, 2000, Manajemen Jasa, Andi Offset : Yogyakarta.

[5] Harto, B. (2015). Analisis Tingkat Kepuasan Pelanggan Dengan Pendekatan Fuzzy Servqual Dalam Upaya Peningkatan Kualitas Pelayanan. Jurnal TEKNOIF, 3(1), 20-30.

[6] Bakhtiar, A., Susanty, A., \& Massay, F. (2012). ANALISIS KUALITAS PELAYANAN YANG BERPENGARUH TERHADAP KEPUASAN PELANGGAN MENGGUNAKAN METODE SERVQUAL DAN MODEL KANO (Studi Kasus: PT. PLN UPJ Semarang Selatan). J@ti Undip: Jurnal Teknik Industri, 5(2), 77-84. https://doi.org/10.12777/jati.5.2.77-84

[7] Parasuraman, A., Zeithalm, V., dan Berry L., 1988, SERVQUAL: A Multiple item Sale for Measuring Consumer Perceptions of Service Quality, Journal of Retaliling

[8] Parasuraman, A., Zeithalm, V., dan Berry L., 1985, A Concept Model of Service Quality and Implication for Future Research, Journal of Marketing

[9] Sukamto, \& Shalahuddin, 2013, Analisa dan Desain Sistem, Andi Offset, Yogyakarta

[10] Yanto, Robi., 2016, Manajemen Basis Data Menggunakan $M y S Q L$, Deeppublish, Yogyakarta 